\title{
CHAPTER 5 \\ DEVELOPMENT OF METHODOLOGICAL PROVISIONS \\ OF AUDIT OF FOREIGN TRADE ACTIVITIES OF RELATED ENTERPRISES
}

Fesenko V. V.

\section{INTRODUCTION}

The international business globalization as well as Ukraine's integration into the world economic relations foster an increase in business activity of foreign corporations in the Ukrainian market and, accordingly, domestic entities engaged in foreign trade activities abroad. This leads to a growing number of audits both at the level of independent professional audit and government tax control. The European integration processes in Ukraine during recent years have accelerated a gradual implementation of the EU standards into the global business concerning taxation, control and audit approval of public financial statements of certain enterprises engaged in foreign trade activities as well as groups of international companies.

Transformational changes in the global and national economic practice require the improvement of methodological approaches to the analysis of foreign economic activity of enterprises, which will raise the efficiency of audit at different organizational levels of its conducting. Thorough scientific researches aimed at developing the areas of application of methods of analysis while carrying out the audit of foreign economic activity are essential to reinforce the economic security of certain entities engaged in foreign economic activity and a country as a whole.

The gradual implementation of the Organization for Economic Cooperation and Development roadmap to counteract tax base erosion and profit shifting is held through adapting the provisions of the Tax Code of Ukraine concerning transfer pricing control to the European standards. This demands an accounting and analytical support to draw up a report on controlled transactions and submit it to the State Fiscal Service of Ukraine. One of the types of foreign trade transactions, which are defined as controlled in accordance with the requirements of the Organization for Economic Co-operation and Development and the Tax Code of Ukraine, are foreign trade transactions with related parties. Their nature elevates the risk of substantial deviations of financial statements as well as creates the 
possibility of manipulating the terms of foreign trade agreements in order to obtain illegal benefits. Taking the abovementioned into consideration, in the context of the implementation of the European standards in regards to conducting and controlling business the research in the field of audit and analysis of foreign economic activity of related enterprises is becoming a mainstream.

\subsection{Theoretical foundations for the development of audit and analysis as a type of information interaction}

In the current conditions of globalization and much wider participation of Ukrainian enterprises in international business relations, audit is increasingly becoming an effective tool for ensuring the quality and reliability of financial and non-financial information reflected in the reports of enterprises. At the same time, the importance of tax audit is growing, especially concerning the results of foreign economic activity (hereinafter FEA) of enterprises. Thus, the updating of the audit as a form of financial control by various audit entities requires a thorough research into this area and clarifying the role of audit in the current business environment.

Overall, the term "audit" in modern researches is studied by representatives of various scientific directions of both macro- and microlevels, among which there are researches into public administration, company management as well as accounting and auditing.

Studies of the practical aspects of audit in Ukraine as a control process confirm the existence of audit at different organizational levels and its enforcement by relevant agencies at these levels, including:

- at the level of control over the use of government funds - by the State Audit Service of Ukraine;

- at the level of state tax control over entities - by departments of auditors of the State Fiscal Service of Ukraine;

- at the level of state Customs control - by Customs auditors of the State Fiscal Service of Ukraine;

- at the level of independent professional financial control over entities - by certified independent audit firms and individual private auditors;

- at the enterprise level - by internal auditors.

The aim of their activity is different, so it is important to distinguish an objective and subjective level, at which further scientific research will be conducted. 
Over the past quarter century, several Nobel Prizes in economics have been awarded to scientists whose studies from different sides deal with the information interaction of objects of various economic systems:

- in 1994 - to John Harsanyi, John Nash, Reinhard Selten- for their pioneering analysis of equilibrium in the theory of non-cooperative games;

- in 1996 - to James Mirrlees, William Vickrey - for their fundamental contributions to the economic theory of incentives under asymmetric information;

- in 2001 - to George Akerlof, Michael Spence, Joseph Stiglitz - for their analyses of markets with asymmetric information (founders of information economic theory);

- in 2016 - Oliver Hart, Bengt Holmstrom - for their contributions to contract theory;

- in 2017 - Richard Thaler - for his contributions to behavioral economics.

The analysis of researches by Nobel Prize winners confirms that the world economic science is more and more directing towards the behavioral aspects of the development of economics as a science, which are known to be based on information interaction.

This points to the relevance of scientific research into accounting, analysis and, in particular, audit, which is still unreasonably considered as a research field with a low scientific innovation potential.

In the course of audit information interaction is made among the largest number of persons including accounting staff, auditors, business owners, potential shareholders, creditors, representatives of state control agencies, investment companies, international donor organizations etc.

While exploring the works of European scholars, P. Welt ${ }^{1}$ emphasizes that the quality of external audit should prevent accounting scandals observed in past and reduce the level of fraud at the management level, thereby positively affecting corporate governance effectiveness, which virtually results in greater efficiency of capital market. P. Welt considers three key aspects of contemporary audit development as a field of research: the quality of audit; audit costs; the concentration of the audit services market.

To improve the quality and reduce the cost of audit P. Welt offers a joint audit to decrease an auditor's dependency and bias as well as

\footnotetext{
${ }^{1}$ Velte, P. (2017). What do we know about empirical joint audit research? A literature review. Accounting and Financial Control, 1(1), 4-14.
} 
information asymmetry. In his opinion, the theory of a chief economic agent (auditor) and a shareholder as a dominant concept of audit development still remains the most relevant.

The enforcement of joint audit, which is to carry out audit procedures by several auditors, is a prospective field of research in this area.

The discussion on joint audit and its impact on the quality of audit reports and the volume of audit costs is presented in many researches. Scientists say that exercising audits by several experts from different firms can improve its quality and reliability, which will positively affect public confidence in the financial statements of enterprises and the reputation of auditors as economic agents. However, the issue of the costs of such an audit and the its impact on the market concentration of audit services remains debatable ${ }^{2}$.

The introduction of joint audit into auditing practices of Ukrainian enterprises can have an ambiguous effect. On the one hand, it is required to reinforce the credibility of the financial statements approved during such audits, yet on the other hand, due to rising costs, businesses subject to statutory audit can counteract it.

In the international practice joint audit is abundantly used to approve the reports of multinational corporations. The benefit and effectiveness of joint audit is achieved through:

- distribution of responsibilities between several auditors;

- possibility of two-sided verification of the results of joint work;

- increased independence of auditors and unbiased audit.

At the current stage of audit development in Ukraine it should be pointed out that domestic researches into audit are influenced by the US and the EU experience. Ukrainian scientists study audit generally in alignment with the scientific publications of the US scholars, in which audit is considered as a form of independent professional control and evaluation of reliability of the financial information of enterprises (especially of corporate type).

A variety of concepts and theories of the occurrence of audit is conditioned by the nature of information interaction between the participants in the audit process (subjects of audit, users of audit findings and other stakeholders dealing with the results of enterprises' activity). For example, according to the theory of owner the role of an auditor is to

\footnotetext{
${ }^{2}$ Baldauf, J., \& Steckel, R. (2012) Joint Audit and Accuracy of the Auditor's Report. An empirical study. International Journal of Economic Sciences and Applied Research, 5, 7-42.
} 
provide appropriate guarantees to current and potential investors, which is made through information interaction between CEOs and capital owners. The latter can set expected levels of return on capital for managers to evaluate management activities, while managers provide owners with retrospective information on the results achieved and prospective information on the projected results of transactions, expected risks and other necessary information.

In addition, the theory of audit adequacy should be mentioned, which implies that the main function of audit is to verify the compliance of the subject of audit with the specific requirements of legislation or regulatory provisions. With reference to the theory of adequacy, an auditor also represents the interests of an owner (like in the theory of owner), but with a greater focus on assessing the relevance and accuracy of data.

There is an idea about the existence of the theory of controlling as one of the elements of the theory of audit. However, in our opinion, it is more appropriate to consider controlling as a function of an entity's management. Still, control and controlling functions are closer to the managerial ones.

The theory of agents is more popular in modern scientific researches, as it is consistent with current trends of considering corporate reporting as the main information tool to ensure public confidence in economic data of entities. Therefore, according to the theory of agents the list of potential users of audit findings significantly increases due to an expanded range of users of modern public corporate reporting, in which all economic information is presented in view of the influence on the social-economic development of society as a whole. In particular, reports of numerous public enterprises already include the information on compliance of their activity with environmental requirements, social responsibility and other non-financial characteristics of enterprises' activity (Table 1).

Several studies of Ukrainian scientists devoted to the development of concepts and organizational elements of the completion of corporate financial and non-financial reporting have been published recently, which also increases the relevance of research into auditing of reports. Among all other reasons for occurrence of audit as a professional independent control special attention should be paid to the territorial branching of business. Due to the globalization processes and integration of the Ukrainian business into the European and world space, audit is especially required for international corporations, where the control of owners is weakened by the geographical remoteness of the individual branches of corporations. 
Table 1

\section{Features of information interaction in the context of the theories of audit occurrence}

\begin{tabular}{|c|c|c|c|}
\hline Indicators & The theory of owner & The theory of agents & $\begin{array}{c}\text { The theory } \\
\text { of incentives }\end{array}$ \\
\hline $\begin{array}{c}\text { The role of an } \\
\text { auditor as an } \\
\text { information agent }\end{array}$ & $\begin{array}{c}\text { An audit or guarantees } \\
\text { the integrity and } \\
\text { reliability of } \\
\text { management }\end{array}$ & $\begin{array}{c}\text { An auditor acts as an } \\
\text { economic agent for a } \\
\text { wide range of users }\end{array}$ & $\begin{array}{c}\text { An auditor acts as a } \\
\text { controlling body }\end{array}$ \\
\hline $\begin{array}{c}\text { The nature of } \\
\text { information } \\
\text { interaction }\end{array}$ & $\begin{array}{c}\text { An audit or confirms } \\
\text { the information } \\
\text { interesting for an } \\
\text { owner }\end{array}$ & $\begin{array}{c}\text { An audit or confirms } \\
\text { the information } \\
\text { contained in public } \\
\text { reporting }\end{array}$ & $\begin{array}{c}\text { An auditor verifies the } \\
\text { compliance of the } \\
\text { reporting data with } \\
\text { legal provisions }\end{array}$ \\
\hline $\begin{array}{c}\text { The subject of } \\
\text { audit }\end{array}$ & Activity & Public reporting & External reporting \\
\hline
\end{tabular}

Source: completed by the author

The annual reports of the United Nations Conference on Trade and Development (UNCTAD) confirm the fact that the internationalization of the world economy is high, which results in the appearance of a significant proportion of foreign assets and foreign profits of multinational corporations (Table 2).

The analysis of the statistical indicators of internationalization of the world's 100 largest non-financial TNCs shows that within the structure of their assets more than half of them (62-63\%) are assets located out of the country of registration of a controlling enterprise. At the same time, the main part of the income of such TNCs is also generated abroad, in particular, the share of foreign revenues in total sales was $63 \%$ in 2015 , $64 \%$ in $2016,65 \%$ in 2017 . A slightly smaller share of foreign assets and revenues of TNCs from emerging and transition economies was noticed.

The data presented highlight the need for a modern audit concept that would take into account the process of economic internationalization and ensure the reliability of economic information in the context of its growing role in the social-economic development of the world.

Since the requirements for audit quality are generally determined by public needs, the scientific task is to identify specific socially relevant characteristics of audit itself and other auditing services, the level of auditors' responsibilities as well as specify audit tasks of public importance.

Considering the concept of joint audit as a modern form of verification and approval of financial statements of enterprises for a wide 
range of information users, it is possible to specify several more forms of joint audit (Figure 1).

Table 2

\section{Statistical indicators of internationalization of the world's 100 largest non-financial TNCs, emerging and transition economies}

\begin{tabular}{|l|c|c|c|c|c|c|c|}
\hline \multirow{2}{*}{$\begin{array}{c}\text { Statistical indicators } \\
\text { of internationalization }\end{array}$} & \multicolumn{3}{|c|}{\begin{tabular}{c}
\multicolumn{3}{|c|}{ The world's 100 largest } \\
TNCs
\end{tabular}} & $\begin{array}{c}\text { Growth } \\
\text { index } \\
(2017 /\end{array}$ & \multicolumn{3}{c|}{$\begin{array}{c}\text { 100 largest TNCS from } \\
\text { emerging and transition } \\
\text { economies }\end{array}$} \\
\cline { 2 - 6 } & 2015 & 2016 & 2017 & $2015)$ & 2015 & 2016 & 2017 \\
\hline $\begin{array}{l}\text { Foreign assets, billion US } \\
\text { dollars }\end{array}$ & 8015 & 8337 & 9004 & 1,12 & 1716 & 1886 & $\mathrm{x}$ \\
\hline $\begin{array}{l}\text { Internal assets, billion US } \\
\text { dollars }\end{array}$ & 4875 & 4894 & 5491 & 1,13 & 4289 & 4511 & $\mathrm{x}$ \\
\hline $\begin{array}{l}\text { Total assets, billion US } \\
\text { dollars }\end{array}$ & 12891 & 13231 & 14495 & 1,13 & 6004 & 6397 & $\mathrm{x}$ \\
\hline $\begin{array}{l}\text { Share of foreign assets in } \\
\text { total assets, } \%\end{array}$ & 62 & 63 & 62 & 1 & 29 & 29 & $\mathrm{x}$ \\
\hline $\begin{array}{l}\text { Foreign sales revenue, } \\
\text { billion US dollars }\end{array}$ & 4802 & 4765 & 5170 & 1,08 & 1734 & 1559 & $\mathrm{x}$ \\
\hline $\begin{array}{l}\text { Domestic sales revenue, } \\
\text { billion US dollars }\end{array}$ & 2851 & 2737 & 2793 & 0,98 & 1903 & 1965 & $\mathrm{x}$ \\
\hline $\begin{array}{l}\text { Total sales, billion US } \\
\text { dollars }\end{array}$ & 7653 & 7502 & 7964 & 1,04 & 3638 & 3524 & $\mathrm{x}$ \\
\hline $\begin{array}{l}\text { Share of foreign revenues } \\
\text { in total sales, } \%\end{array}$ & 63 & 64 & 65 & 1,03 & 48 & 44 & $\mathrm{X}$ \\
\hline
\end{tabular}

Source: completed by the author on the basis of the World Investment Report 2018 of the United Nations Conference on Trade and Development ${ }^{3}$

Joint corporate audit is based on information interaction between internal auditors of an enterprise and external auditors, which confirms the reliability of public reporting. The exchange of information on an entity's activities to be verified should ensure the effectiveness of external audit and reliability of independent audit. Hence, the effectiveness of an audit is viewed as achieving a sufficient level of confidence in an entity's public reporting with minimum involvement of external auditors. The result of audit is a reasonable and correct conclusion of an external auditor regarding the outcomes of independent audit of the reporting.

\footnotetext{
${ }^{3}$ World International report 2018. New York and Geneva, 2018. Investment and new industrial policies. Retrieved from: http://unctad.org/en/pages/PublicationWebflyer.aspx?publicationid=2130
} 

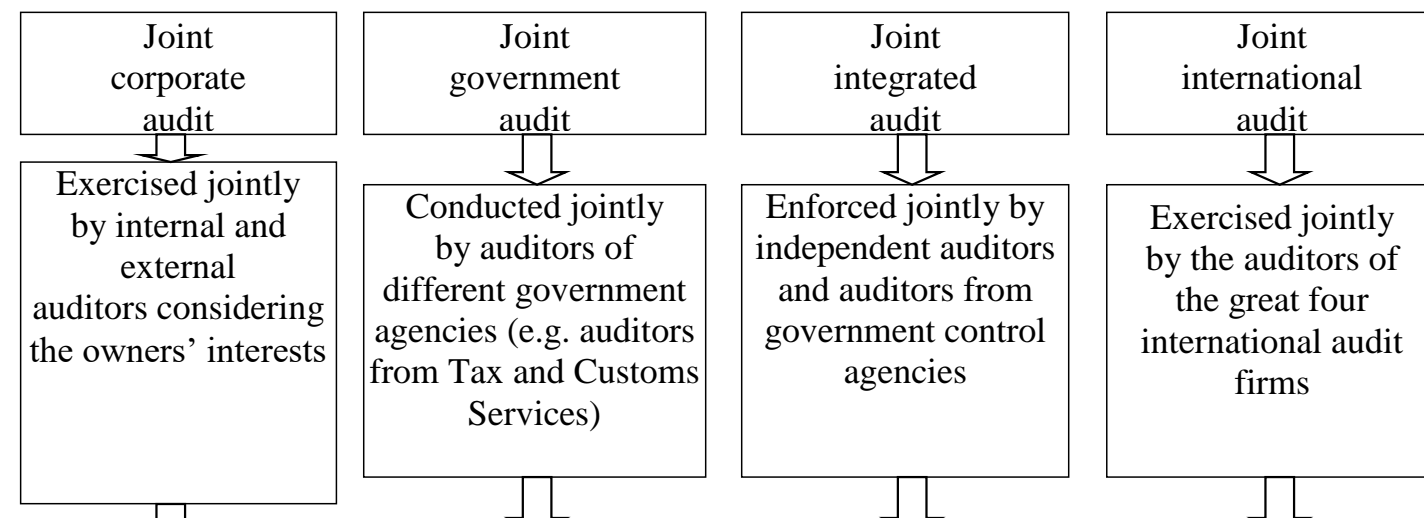

by auditors of

Enforced jointly by independent auditors and auditors from different government agencies (e.g. auditors from Tax and Customs Services)
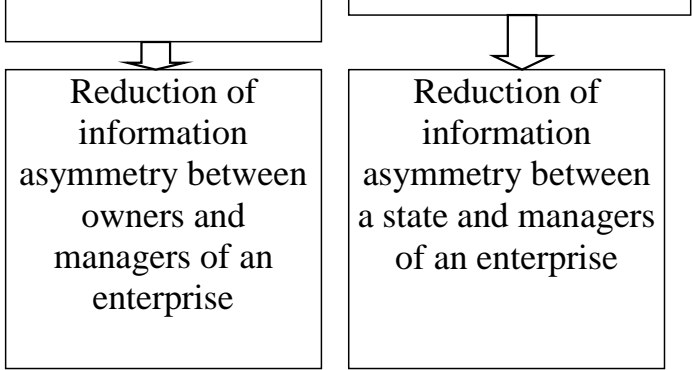

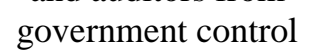

agencies

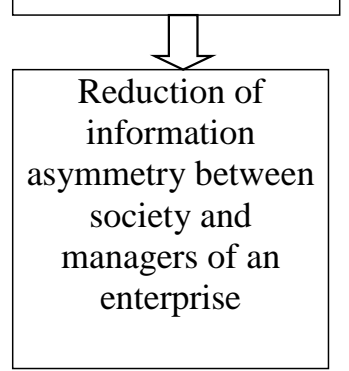

Exercised jointly by the auditors of the great four international audit firms

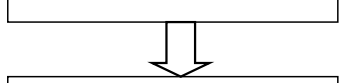

Reduction of information asymmetry between owners, society and managers of an enterprise

\section{Figure 1. Forms of joint audit as a tool to restrict information asymmetry}

Source: completed by the author

Joint government audit is recommended to be exercised as a form of state financial control with the involvement of experts from different agencies of the State Fiscal Service of Ukraine, which will allow raising the efficiency of control over the correctness of taxes calculation and payment by entities, including an exchange of audit findings between Customs officials, who carry out Customs control, and representatives of the Taxation Service of the State Fiscal Service of Ukraine, which enforces tax control (audit).

Joint corporate audit and joint government audit have slightly different goals. In particular, corporate audit is focused on taking into account the interests of investors, owners, creditors regarding the reliability of financial data and results of business activities of entities. Accordingly, audit enforced by public authorities is aimed at checking the correctness of taxes calculation and payment. So, various directions of the abovementioned controls are governed by polar goals of information users, which causes the risk of information asymmetry in the economic decision making process based on the results of such audits.

The concept of information asymmetry was studied by George Ackerloff, Michael Spence and Joseph Stiglitz within the researches into information economics. The idea of information asymmetry is that during information interaction participants in economic activities have an 
inappropriate amount of information, which leads to the information superiority of some participants and lack of information for other ones. The scientists mostly investigated market exchange of goods, however, they also noticed that information asymmetry could occur during any interaction of subjects of different economic systems, in particular, between public authorities, between entities etc. Information asymmetry can also arise during information interaction between managers, auditors as well as current and potential users of company reporting.

The use of different forms of joint audit will reduce the level of information asymmetry due to the information interaction of representatives of different types of audit. Therefore, joint integrated audit is proposed to be enforced on the basis of information interaction between independent auditors and auditors of government control authorities through the exchange of audit findings, which will allow increasing the effectiveness of audits.

A joint international audit is based on information interaction between the auditors of the great four international audit firms (Pricewaterhousecoopers, Deloite, ErnstandYong, KPMG), which ensures the efficiency of independent auditing of companies, especially international ones.

The introduction of joint audit into the system of independent professional audit of an enterprise's reporting requires defining the characteristics of such an audit task (service), the level of auditors' responsibility and the conditions of information interaction of auditors involved in joint audit. In our opinion, all these forms of joint audit can be exercised as a task of giving an assurance, which determines the highest degree of auditor responsibility in performing it and requires the highest level of auditors' sufficient assurance.

Information interaction between subjects of different economic systems is based on the idea of "information" and "value of information". The validation of information on the results of an enterprise's activity for external users demands an auditor's competent approach, which means understanding the essence of information and responsible attitude to information interaction with company managers, users of public reporting data of enterprises and other auditors.

\subsection{Methodology of audit of foreign economic activity of related enterprises}

The audit of foreign trade activities of enterprises is gradually being transformed into a new form, which is an integrated system of interaction 
between different types and subjects of audit. The main strategic goal of such integration is to ensure the transparency of international business operations and reliability of the reporting of entities involved in foreign economic activities. The result of integration in the short run can be the creation of a unified methodology for auditing foreign economic transactions and information interaction between audit agencies - the State Tax Service of Ukraine, independent auditors, internal corporate auditors, Customs auditors and auditors of foreign enterprises. Improving the quality of all types of audit of foreign trade operations and widening information interaction between audit agencies will help to reduce the level of information asymmetry and increase the effectiveness of audits.

Therefore, the audit of a company involved in foreign trade is a form of information interaction between the principals of economic information (state, owners, society, investors, creditors) and agents of audit activity (tax auditors, independent professional auditors, internal corporate auditors) regarding tax, independent external and internal audits.

Determining the priority areas for audit of foreign trade operations is primarily based on specifying the abovementioned companies' areas with the highest risk of errors and intentional accounting violations (frauds). Such frauds can be committed through a variety of ways and with different purposes, which essentially distinguishes fraud schemes by the criterion of influence on entities' reporting and consequences of their implementation. However, not only the nature of fraud impacts on audit procedures of the companies involved in foreign trade activities, but also audit goals create the key directions of control. Hence, it is necessary to distinguish the audit of foreign trade operations as a part of independent audit of financial statements in order to confirm their reliability. The main feature of this audit is to create an independent opinion on the reliability of the data for users of financial statements - owners, potential investors, creditors etc. Therefore, the audit is exercised to identify those risks of fraud that may lead to hiding the facts of assets embezzlement or manipulating users' decisions.

For the last few years a so-called tax audit of foreign trade operations has increasingly gained significance as an integral part of state fiscal control. Such checks are already focused on the interests of a state and are carried out by government authorities. The purpose of tax audit of foreign trade transactions is to reveal the cases of tax evasion and moving national assets out of a state. 
While analyzing the priority directions of audit of companies involved in foreign trade, purposes of fraud schemes and accounting violations should be taken into account. The goals, which companies breaking legislative and regulatory requirements pursue, determine the ways of their commitment and concealment. Accounting violations within accounting of foreign trade transactions are generally committed with the aim of:

- tax evasion;

- concealment of assets embezzlement;

- manipulation of economic decisions of users of the financial reporting of entities involved in foreign trade activities;

- concealment of illegal withdrawal of national assets (Figure 2).

FORMS OF INFORMATION ASYMMETRY

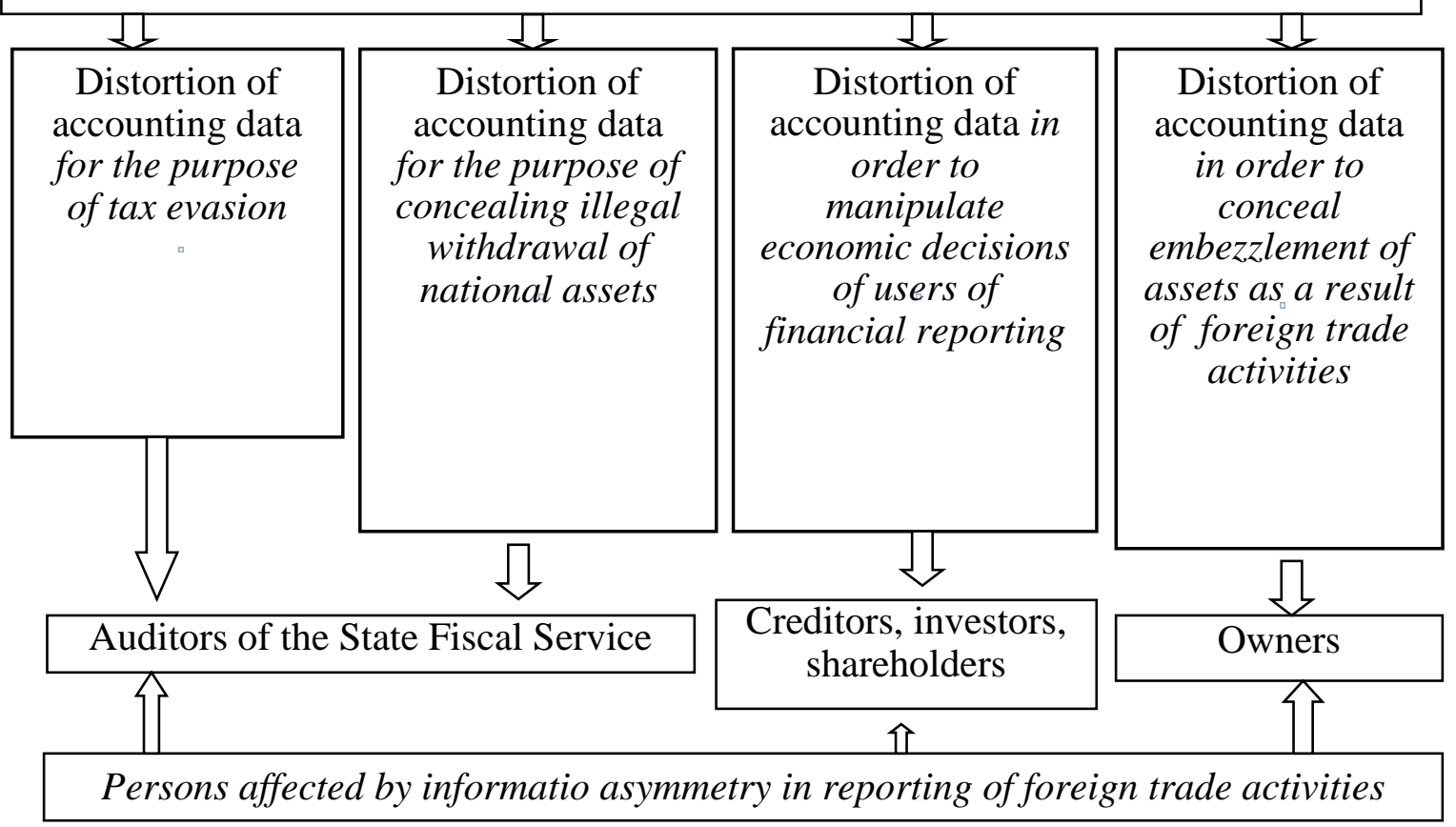

\section{Figure 2. Types of information asymmetry between management and users of financial statements of enterprises}

Source: completed by the author

Such violations lead to information asymmetry between different persons, which should be subject to audit of enterprises involved in foreign trade activities exercised by different audit agencies.

Different goals result in the use of different fraud schemes and mechanisms and, therefore, can be identified by using appropriate indicators. Establishing a system of indicators will allow audit agencies to identify risks of fraud through specific indicators and direct audit 
procedures specifically to the company's activities that are suspicious, high-risk and ambiguous.

The occurrence of the fraud in the field of foreign trade transactions with related parties results in significant losses and economic harm to both Ukraine and certain entities involved in foreign trade activities.

The experience of individual countries in the field of financial control of foreign trade operations of enterprises is diverse and, above all, related to Customs audit.

Customs control and control of transfer pricing are different elements of the overall system of financial control of foreign trade operations. In Ukraine the control of Customs duties is divided into: control at the border crossing points by Customs inspectors respectively; further control over the accrual and payment of Customs duties and other taxes is exercised by tax authorities.

The control of transfer pricing is linked to the operations of multinationals, whose activities allow their managers to negotiate foreign economic transactions on terms that are favourable for them, but not for the countries where they operate in terms of taxation. In addition, a transfer price itself has a greater impact on the corporate income tax, which is not included in Customs duties.

The abovementioned facts confirm that the development of the audit of foreign trade activity of Ukrainian enterprises is currently happening due to strengthened tax audits of foreign economic transactions, expansion of independent external and internal audits of enterprises involved in foreign trade activity, which requires improving the methodology of audit of foreign trade activity of enterprises.

The category of methods is key in determining the nature of the methodology of audit of foreign trade activities of related enterprises. Researchers specify the following special techniques and methods of audit: observation, questioning, confirmation, analytical review, scanning, recalculation, cross-checking, generalization, inspection, analysis etc.

The conventional structure of the methodology of audit incorporates relevant audit hypotheses, which are used as axioms of audit science and build the basis of the methodology of audit in general.

In order to outline a specific methodology for the audit of foreign trade activities of related enterprises additional claims should be specified:

1. The information on foreign trade activities of related companies is of public interest and should therefore be monitored by various control 
agencies (government, independent audit, owner) and be accessible to all audit agents.

The financial statements of the entities involved in foreign economic activities are of interest to a large number of agents as they are shaped by globalization and integration processes.

2. Foreign trade transactions between related enterprises include high risk of distortion and therefore require a greater number of audit procedures compared to foreign trade transactions between unrelated enterprises.

The risk of affecting related enterprises' business transactions involves additional risks for minority shareholders who have own shares in an enterprise's capital, but limited influence on control and management of the business.

3. The reliability of foreign trade operations results, their efficiency and compliance with the tax legislation are core factors for reinforcing the economic security of a state, entities and capital owners.

Offshore zones, expansion of international trade, globalization of international business bring about additional risks of national capital tax evasion as well as national enterprises' equity erosion.

The additional claims proposed for the audit of foreign trade operations of related enterprises are consistent with current principles of transparency, reliability and integrity of economic information within the theory of agents.

The main methodological principles for the audit of foreign trade operations of related enterprises are the "arm's length" principle, the principle of consistency, transparency, efficiency and the principle of risk targeting.

Enforcing an audit according to the "arm's length" principle involves reviewing the terms of foreign trade transactions to ensure that they are market-relevant (transactions between related parties must be conducted on the same terms as those between independent parties), which guarantees integrity and fairness of the transactions.

The principle of consistency involves the audit of foreign trade operations of related enterprises as a single entity consisting of various interrelated elements. The "risk targeting" principle is an integral part of contemporary audit of any field and involves appropriate audit procedures to check areas of accounting with high risk of distortion.

Based on the application of the abovementioned claims for external, internal and tax audit, such kind of the methodology for audit of foreign trade operations of related enterprises can be outlined (Figure 3). 


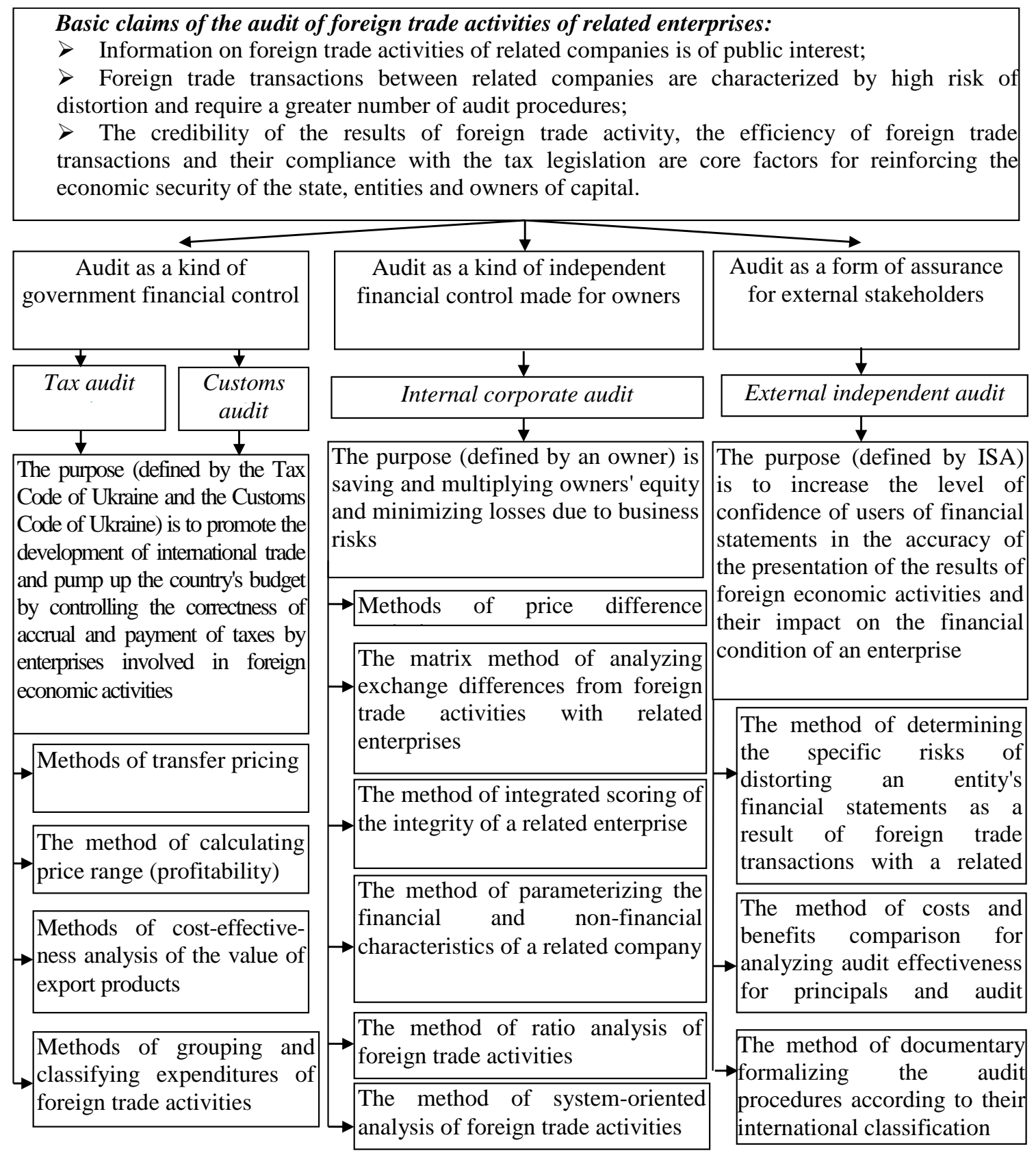

\section{Figure 3. Methodology of audit of foreign economic activities of related enterprises}

\section{Source: completed by the author}

The application of different methods of audit and analysis of enterprises involved in foreign trade activities is dependent on the purpose of certain types of audit, whether it is an external independent, internal corporate or external tax one. In particular, the structural elements the methodology for audit and analysis of foreign trade activities of related enterprises include the principles (arm's length, transparency, efficiency, consistency, risk-targeting); the claims of the audit of foreign trade 
activities of related companies (Figure 3); levels of enforcement (international, state, corporate); audit agents (tax auditors, independent auditors, internal corporate auditors); types (tax, internal, independent); principals (shareholders, owners, state, representatives of foreign tax inspections); forms (operational, strategic, external, internal); methods (analytical methods are consistent with the purpose of the audit of foreign trade activities).

Audit as a form of government financial control is currently exercised through tax and Customs audit of foreign economic activities of enterprises by representatives of the State Fiscal Service of Ukraine and aims to control the compliance of accrual and payment of taxes by enterprises involved in foreign trade activities with the requirements of the Customs and Tax Codes of Ukraine. The audit agents are government representatives who have an appropriate level of dependence on the orders of their managers and the use of control methods recommended by the regulatory documents. The nature of the methodology of this type includes a consistent application of analytical methods to confirm the feasibility of transfer prices in foreign economic transactions through the calculation of the price range (profitability) in accordance with the principle of "arm's length". In order to ensure that this type of foreign trade activity of related enterprises is in compliance with the abovementioned claims, we consider it reasonable to develop a methodological approach to the transfer price feasibility based on an analysis of the enterprise costs closely connected with foreign trade operations.

\section{CONCLUSIONS}

In the conditions of developing the behavioral world economic science the issue of information interaction of a large number of persons including accounting staff, auditors, business owners, potential shareholders, creditors, representatives of government control agencies, investment companies, international grant organizations etc. is becoming more and more up-to-date. The nature of information interaction between them leads to information asymmetry, which should be reduced through the introduction of audit of financial and non-financial information. Due to the globalization processes and integration of domestic business into the European and world economic space, characterized by a significant share of foreign assets and foreign revenues of multinational corporations, the audit of foreign trade operations of international corporations is becoming more and more important, since the control of owners is weakened due to 
the geographic remoteness of individual branches of corporations. This highlights the need for defining a modern audit concept for taking into account the internationalization of the economy aimed at ensuring the reliability of economic information in view of its growing role in the social-economic development of the world. It has been proved that joint audit exercised by several auditors decreases the level of information asymmetry between principals and agents of audit services. This conclusion allowed offering several forms of joint audit as a modern stateof-the-art form of the process of verification and approval of enterprises' financial statements for a wide range of users of information, including joint corporate audit, joint government audit, joint integrated audit and joint international audit.

The analysis of theoretical research into audit makes it possible to claim that the audit of foreign trade activities is studied according to several conceptual directions: as an element of fiscal policy in the field of public financial control or as an element of independent financial control made in the interests of the owners of enterprises involved in foreign trade activities by means of external and internal audit. The types of audit of foreign trade activities of enterprises according to information inquiries and purposes of users of information on an enterprise have been specified and distinguished by purpose and audit agents. The audit of foreign trade activities in the current economic conditions of Ukraine is one of the essential factors for improving the level of economic security of both the country and individual companies engaged in foreign trade. This implies identifying a range of new scientific and practical tasks of the audit of foreign trade operations, including the development of a methodological basis of audit and analysis of transfer prices within controlled transactions with related parties as a part of tax audit exercised by the State Fiscal Service of Ukraine; building the methodology of internal audit and analysis of foreign trade operations of enterprises within the activity of the group of international companies; improving the methodology of external independent professional audit of financial reporting of companies making transactions with related parties.

\section{SUMMARY}

The specific nature of the audit of foreign economic activities of related enterprises requires a clarification of methodological approaches to carrying out such inspections, since foreign economic transactions appeal to different auditors from several areas of financial control. To outline a 
specific methodology for the audit of foreign economic activity of related enterprises, additional audit principles have been specified in this area as well as the methods of three types of audit of foreign economic activity as a complex of analytical methods of audit research have been identified.

The essence of an audit of foreign economic activity of an enterprise as a form of information interaction between principals of economic information (such as a state, owners, a society, investors, lenders) and audit agents (tax auditors, independent professional auditors, internal corporate auditors) in terms of a tax, independent external and internal audit has been studied and specified. It has contributed to substantiating a role and offering forms of joint audit of foreign economic activity of an enterprise, which provides for conducting an audit by independent, public, domestic and international auditors on the ground of a company's integrated database that reduces information asymmetries as well as decreases audit costs.

The current trends in the field of providing audit services to enterprises - subjects of foreign economic activity have been identified, which allows for supplementing the current classification of audit services with specific services in the field of foreign economic activity of related enterprises, characterized in compliance with the International Auditing and Assurance Standards Board's (IAASB) International Framework for Assurance Engagements. The study of the fundamental distinctions between the types of audit tasks consistent with the requirements of the International Standards on Auditing and clients' requests for audit services has made it possible to classify audit tasks in the field of foreign economic activity into the following: an assurance engagement on the results of foreign economic activity of an enterprise, an assurance engagement on transactions with related parties, review of a report on controlled transactions, preparation of a report on controlled transactions, consulting on transfer pricing substantiation within a controlled foreign economic operation.

\section{REFERENCES}

1. André, P., Broye, G., Pong C., \& Schatt, A. Are Joint Audits Associated with Higher Audit Fees? European Accounting Review, 25, 245-274.

2. Baldauf, J., \& Steckel, R. (2012) Joint Audit and Accuracy of the Auditor's Report. An empirical study. International Journal of Economic Sciences and Applied Research, 5, 7-42. 
3. Bédard, J., Piot, C., \& Schatt, A. (2016). An evaluation of the French expertise with joint auditing. Working paper.

4. Bisogno, M., \& De Luca, R. (2016). Voluntary Joint Audit and Earnings Quality. Evidence from Italian SMEs. International Journal of Business Research and Development, 5, 1-22.

5. Clifford, S. (2019). Taxing multinationals beyond borders: Financial and locational responses to CFC rules, Journal of Public Economics, 173, 44-71. https://doi.org/10.1016/j.jpubeco.2019.01.010

6. Corporate Tax Haven Index (2019). Retrieved from: https://www.corporatetaxhavenindex.org/introduction/cthi-2019-results

7. Customs Code of Ukraine. (2012). Retrieved from: http://zakon3.rada.gov.ua/laws/show/4495-17

8. Deng, M., Lu, T., Simunic, D., \& Ye, M. (2014). Do Joint Audits Improve or Impair Audit Quality? Journal of Accounting Research, 52, 1029-1060.

9. Dischinger, M., T., Riedel, N., (2012). Corporate Taxation and the Location of Patents within Multinational Firms, Journal of International Economics, 88(1), 176-185. https://doi.org/10.1016/j.jpubeco. 2010.12.002

10. Eccleston, R., \& Smith, H. (2016). The G20, BEPS and the future of international tax governance. In P. Dietsch \& T. Rixen (Eds.), Global tax governance: What is wrong with it and how to fix it (pp. 175-198). Colchester: ECPR Press.

11. El Assy, M. G. (2015). The Effect of Joint Audit on Audit Quality. Empirical Evidence from Companies Listed on the Egyptian Stock Exchange. International Journal of Accounting and Financial Reporting, 5, 195-207.

12. Elitzur, R., \& Mintz, J. (1996). Transfer pricing rules and corporate tax competition, Journal of Public Economics, 60 (3), 401-422.

13. Francis, J. R., Richard, C., \& Vanstraelen, A. (2009). Assessing France's joint audit requirement. Are two heads better than one? Auditing, 28(2), 35-63.

14. Highlights of the 2015 Index of Economic Freedom: Promoting Economic Opportunity and Prosperity. Retrieved from: http://irr.org.za/ reports-and-publications/occasional-reports/files/index-of-economicfreedom-2015-ighlights.pdf.

15. Holm, C., \& Thinggaard, F. (2014). Leaving a joint audit system: conditional fee reductions. Managerial Auditing Journal, 29, 131-152.

16. Marques, M., Pinho, C., Montenegro, T. (2019). The effect of international income shifting on the link between real investment and 
corporate taxation. Journal of International Accounting, Auditing and Taxation, 36. https://doi.org/10.1016/j.intaccaudtax.2019.100268

17. Velte, P. (2017). What do we know about empirical joint audit research? A literature review. Accounting and Financial Control, 1(1), 4-14.

18. World International report 2018. New York and Geneva, 2018. Investment and new industrial policies. Retrieved from: http://unctad.org/ en/pages/PublicationWebflyer.aspx? publicationid $=2130$

\section{Information about the author:}

Fesenko V. V.

Doctor of Economics, Professor of Department of Accounting, Audit,

Analysis and Taxation, University of Customs and Finance, Ukraine 